\title{
MUSIC EDUCATION IN PRIMARY COMPULSORY SCHOOLS IN CROATIA AND SERBIA FROM 1945 TO 1990, IN THE CONTEXT OF SCHOOL CURRICULA
}

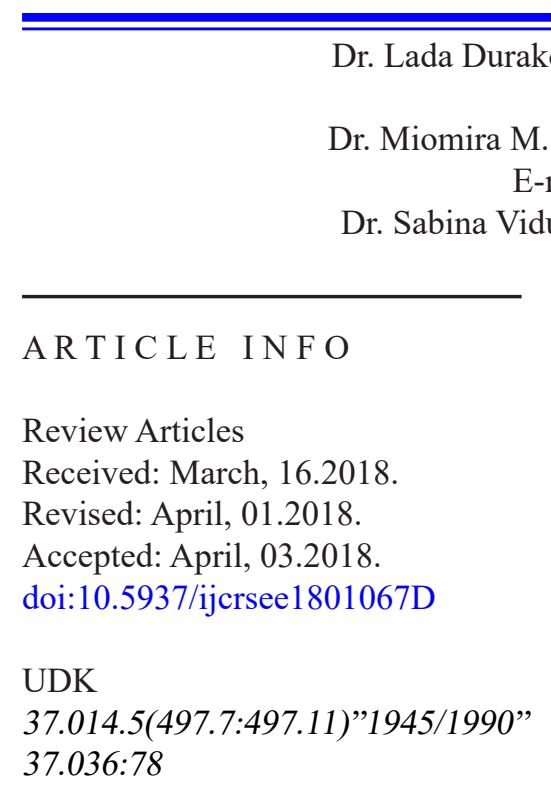

\section{Keywords:}

Croatia,

education,

music lessons,

teaching curricula,

Serbia.

\begin{abstract}
A B S T R A C T
After the Second World War, one of the priorities of cultural policy in the domain of music was the music education of young generations, which was essential to begin with at an early age. Its goal was to form a versatile person prepared for future work and social tasks, an active participant in the cultural and artistic life of his/her environment. Due to the insufficient researches conducted so far on musical education practices in the immediate post second World War period, in this paper we track the contents of the curricula in Croatia and Serbia. It's our intention to emphasize the similarities and the differences in the music educational processes in the two biggest republics of the former Yugoslavia - from the initial lining on the soviet pedagogy trough reforms and changes to a unified conception of schooling on a federal level. The research shows that the curricula were constantly changed and supplemented in the first years after the war. Numerous changes resulted in the changed number of teaching hours and the teaching content, which year by year became more ambitious. The analysis of the curricula from the sixties onwards pointed to new guidelines which advocated the shift from active music playing and acquiring musical literacy to the concept of auditory perception and learning of musicological terminology. Each new syllabus was modified in accordance with the previous one, while taking into account the possibilities of their implementation in practice. Approaching contemporary pedagogical approaches was reflected in the requirements for the application of the model of active participation in the teaching process, the introduction of technological tools and openness to popular music practices.
\end{abstract}

(c) 2018 IJCRSEE. All rights reserved.

\section{INTRODUCTION}

After the end of the Second World War, a new political regime was established in Yugoslavia. The Communist Party had created the overall political strategy, from interior, exterior, economic to cultural policies, and it had constituted a new system of values. The

Corresponding Author

Dr. Lada Duraković, Academy of Music in Pula,

Republic of Croatia

E-mail lada.durakovic@gmail.com

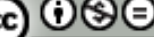

This work is licensed under a Creative Commons Attribution - NonCommercial - NoDerivs 4.0. The article is published with Open Access at www.ijcrsee.com monopoly it held over decision making in all areas of social life enabled it to define a new concept of education in accordance with its own vision, as well as to control and direct the process of transformation of the educational system (Koren, 2012). Caring for the youngest was one of the primary activities of the state and party bodies. It was considered that the state as a political organization had the obligation to set up the goals of education, i.e. that young socialist people should be educated to perform appropriate functions useful to the state (Munjiza, 2009).

Along with the construction of educational infrastructure, it was diligently worked on the socialist upbringing of the youngest generation. The teaching process had to be linked to the contemporary reality of the time, 
while education had to be directed towards the versatile development of a student's personality. The teacher had to be not only a knowledge provider but also a politically aware social worker and educator whose role was to educate young generations in the spirit of the Yugoslavian socialist patriotism, love of the country and its peoples and national minorities (Petrović-Todosijević, 2007).

Changes that took place within the state's economic system, which simultaneously followed the development of science and society and the school system in its entirety, enabled music education to take on a more significant place in the school education system over time. Music education, the professionalism of the teaching, music educated staff, became one of the priorities, and at the same time a condition for the successful realization of music teaching in newly established primary compulsory school which in Croatia and Serbia lasts eight years. Observed through a certain timeframe, from the moment compulsory education was introduced in the school system for everybody, and music classes began to be performed primarily through the subject called Singing, later Musical Education, until the moment it got the name it has kept until today - Music Culture (Jeremić, 2009), music education in Croatia and Serbia has gone through numerous changes. The number of classes that varied from one to two per week, a continuous reformation of the curricula, the teaching contents in which goals and tasks of music teaching were set more closely and more specifically - represent only a part of the changes through which the period of the time related to music education in Croatia and Serbia can be observed.

\section{FROM THE FIRST POST-WAR YEARS TO THE END OF THE SCHOOL REFORM (1945-1958)}

In the first few post-war years, pedagogy and the school system were under the direct influence of the Soviet Union. It was essential for the teaching process to be based on the virtues of etatist values and to be pervaded by the new spirit, the Marxist-Leninist ideology which would, in the future, generate common awareness among the people of the earth (Najbar-Agičić and Agičić, 2006). The early post-war period was marked by the immitation of the Soviet pedagogy and the uncritical acceptance of its pedagogical practice which the ruling party regarded as progressive. Consid- ering the fact that in the pre-war period only the youth from wealthy aristocratic families had been educated, the new government encouraged the education of children from less wealthy families, workers and peasants, "the ideologically and professionally shaped future socialist people" (Šarić, 2013, p. 442). The tendency of forming a young person through educational work resulted in the subordination to the category of the desired model, which sought to make the educational group equal in order to supress the appearance of undesirable elitism. The emphasis was placed on the social conditions and social character of education; a strong ideological influence on education and pedagogy was openly proclaimed. School laws were aligned with federal laws, and all major reforms and changes were based on previously adopted political documents and conclusions.

The starting conditions for educational work were however very unfavorable. The number of illiterate people was great. In rural areas, it was often the case that children had to be absent from classes primarily because of agricultural work or similar obligations (Dobrivojević, 2014). In many places, teaching took place in temporary, inadequate spaces, and the teaching staff was few and insufficiently trained for work. Classes were often conducted by people without adequate qualifications (Puževski, 2003). That period was primarily marked by solving the problems caused by making schools fully state-controlled institutions, by reducing the number of illiterate people, and by creating material conditions for work and teaching. The government gave priority to political and economic issues, while there was no systematic approach in education policy which would result in a complete conception of much needed changes.

After the political conflict and the breakup with the USSR, the period of search for new possibilities, approaches and solutions in school education started. Different models of a compulsory school pointed to the need for a reform of the entire education system. The 1951 People's Schools Act introduced changes in Croatian elementary education, since it proclaimed the general eight-year school compulsory. The transition to eight-year schooling was gradual and different: four-year schools gradually evolved into eight-year schools; the lower grammar school, which became a part of eight-year schooling, was abolished. For the needs of the transformed eight-year school, and on a few occasions, teaching curricula were made and implemented in eight- 
year, six-year and four-year schools, as well as in four grades of the lower grammar school, with the prospect of becoming eight-year schools. The fifties and the beginning of the sixties were marked by the school reform, the development of the so-called third path of the self-governing socialist pedagogy and schooling, and the process of a gradual decline in the influence of the state and politically proclaimed ideology on the education system. Numerous discussions and preparations took place during the reform which began in 1953. In 1958, the unique education system at the federal level was finally defined by the adoption of the General Education Law.

The priorities of the post-war policy in the domain of art reflected in an attempt to create an authentic socialist art compliant with the social and political system. One of the important tasks of cultural policy in the field of music was the music education of the young generation, which had to start from the earliest age. Music education belonged to the field of aesthetic education and along with other educational fields (intellectual, moral, work-related and physical) it made up a whole whose goal was to create a versatile man (Pregrad, 1973). With its content, it had to give a specific contribution to the formation of a harmonious personality. Music education was to prepare a young person for his/her working and social role; it was to strengthen his/her confidence and help him/her to make contributions to cultural development and enrichment of the environment in which he/she lived and worked (Požgaj, 1959).

According to the Law on compulsory seven-year education from 1946, while classroom teaching was conducted in the first four grades, subject teaching was conducted in the next three grades. In the first years after the Second World War, teaching music education in Croatia took place under the name Singing. The aim of the subject in the primary compulsory school, at that time taking four years, and according to the Curriculum from 1946, was the development of hearing, voice and pronunciation, and the training of students for their independent and choral singing. Singing classes were conducted one hour per week. The task of the subject was to encourage young students' interest in music and to develop aesthetic and social components of their personalities. The school curriculum envisaged one-part singing, and if possible, two-part singing of children's, folk and battle songs. Lessons had to begin with songs familiar to children and local songs from the area in which the school was situated, and afterwards to gradually continue with songs from other parts of the country. In accordance with the viewpoint built on the materialistic doctrine, spiritual music was entirely excluded from the school curricula. The connection between music and other educational materials (such as dance, children's games) was greatly encouraged, as was the creation of individual tunes based on suitable children's, national and battle textual templates (Curriculum for primary compulsory schools in the Republic of Croatia, 1946).

According to the curricula for primary compulsory school from 1948, the main task of the course in Singing was to strengthen patriotic, social, and aesthetic feelings and the joy of life and work excitement through the song. Unlike the curricula from 1946, which required singing by ear, the curricula from 1948 introduced very ambitious requirements of elementary music literacy from the third, i.e. the fourth grade with the help of the Tonika-Do method, "using the notes, the intonator and manual signs" (Curriculum for primary compulsory schools, 1948, p. 60; Curriculum for seven-year schools, 1948, p. 62-63; Duraković, 2016; Duraković, 2017). The reason for providing musical literacy was primarily the desire to have the students quickly and better prepared for choral singing. Choral singing was an important educational part of the young socialist man; a place where students took part in the teaching process as active participants in work. In this way, music teaching strengthened education in the spirit of the new ideology. Much attention was paid to understanding song texts, to clear and correct pronunciation, and the vocal technique. In every school, there had to be a choir that was made up of all students. It was thought that "along with proper music teaching based on the curriculum, given time it would become unnecessary to exclude students with so-called weaker hearing" (Curriculum for primary compulsory schools, 1948, p. 62).

According to the curriculum from 1950, Singing classes were given once a week, except for the fifth grade in which a two-hour weekly instruction included singing, voice development and care, rhythm exercises and music aesthetic education. In lower grades, students sang by ear. By their content, the songs related to the home country, school, animals and various children's experiences. From the third grade, the repertoire spread on to national, patriotic, combat and artistic songs. From the fourth grade, with the introduction 
of two-part singing, students gradually adopted the elements of music literacy. They got familiar with the concept of staff; they distinguished notes by duration, tonality, and various measurements. Music dictation was introduced into teaching, as was solmization and the musical alphabet. In addition, listening to selected music works from gramophone records or the radio was included. (Curriculum for eight-year schools and lower grades of the grammar school, primary compulsory schools and extended courses, 1950; Duraković, 2016; Duraković, 2017).

In 1951, The Ministry of Education issued a new curriculum whose content stemmed from the tendency to synchronize it with the first textbooks, i.e. teaching manuals. In this curriculum, along with the subject name Singing in the first three grades, the name Music education for music classes was introduced in upper grades. The change in the name was explained by the need to harmonize the subject with the learning material, which went beyond singing lessons. The number of class hours remained the same. Together with singing and literacy, the new curriculum included all the usual music-educational fields except for playing: listening to music which depended on the conditions of the particular educational institution; music life which consisted mainly of the clarification of certain terms related to music culture, and creative work. In the fifth and sixth grades, acquiring music literacy referred to getting acquainted with the solmization, alphabet, major and minor scales, interval recognition through hearing, etc. The curriculum envisaged writing the dictation of up to four bars in all tonalities, and rewriting the letter notation into absolute notation. In the seventh and eighth grades, some of the assignments were to transpose melodies from one tonality into another, to write dictation up to eight bars, etc. As an aid in the acquisition of basic music knowledge, it was recommended to use the Tonika-Do method, the numeral method (Galin, Paris, Chevé system) with the help of the modulator and manual signs. In these grades, the teacher was supposed to tranfer knowledge on certain great singers and instrumental virtuosos. An active relationship towards a music piece had to be achieved through working on developing music memory and recognition, the ability to distinguish rhythms, melodic movement and the main contours of the music form, composing techniques, etc. Therefore, the teacher was expected to perform short compositions, preferably by Slavic composers (e.g. Chopin, Smetana, Lisinski, Dvořák,
Tchaikovsky, Mussorgsky, Mokranjac, etc.). The so-called internal choir, in which all students participated, was to be organized in each grade. Working with the internal choir took place during teaching, i.e. when the teacher wanted to check whether the students were able to put their acquired knowledge in theory and solfeggio to practice. Next to the internal choir, a school had a representational choir which performed at various events, celebrations, and the like. Taking part in that choir, which was included in the curriculum with two hours per week, was meant for uppergrade students selected by the teacher. A large number of choral performances which represented schools in the public and which accompanied various protocol celebrations created the need to select students with proper intonation, who were able to raise the quality of the performance to a satisfactory level (Curriculum for eight-year schools and lower grades of the grammar school, 1951).

In 1954, the Curriculum for national four-year and six-year schools and lower grades of the grammar school was published; a year later, the Curriculum was published for people's six-year schools, and then the Temporary Curriculum for the seventh and eighth grades of the primary eight-year compulsory school, in which the content of Music education teaching classes remained very similar to the previous one, and it took one hour per week in every grade (Curriculum for people's four-year schools and lower grades of primary compulsory schools, 1954).

Similar to Croatia, after the Second World War, the period of numerous social and political changes in the state took place, which incited a series of changes within the Serbian school system. In the curricula which referred to Singing classes in primary compulsory schools in Serbia, significant differences can be seen in relation to the previous curricula, while the teaching content from the first to the fourth grade indicates that the teaching process in this period of schooling was primarily based on singing songs. Conducted one hour per week, Singing classes had, in essence, the goal to: develop hearing, voice and singing abilities of students for individual and choral singing, strengthen patriotic, social and aesthetic sentiments and provide students with the basic knowledge in music theory. The teaching material was divided into general (it was present in the first and second grades, and it meant a preparation for notational singing) and special (it was present in the third and fourth grades, the period in which notational singing 
began to get combined with classes of music theory) (Curriculum for primary compulsory schools with didactical instructions for teaching particular subjects, 1945). This tendency remained present in the next few years. In the decades following the Second World War, the school system was designed in such a way that the content which could be connected to the Orthodox spiritual tradition was entirely excluded from the curriculum. Orthodox music remained almost unmentioned during schooling with the exception of Kornelije Stanković and Stevan Mokranjac, of whom it was merely noted on a few rare occasions and in footnotes that they also practiced Serbian spiritual music. Efforts to modernize teaching posed great problems and required additional for both classroom teachers and subject teachers, who were not yet educated for its implementation in the post-war period.

In this way, in the curriculum for primary compulsory schools from 1947, the acquisition of music literacy, which was supposed to start from the fourth grade, began to be insisted upon with the intention of preparing students for independent singing in class, and also for subsequent two-part or multi-part choral singing (Curriculum for primary compulsory schools from 1947 and 1948 school years, 1947). Special attention was paid to singing which was accompanied by dancing.

Singing in the choir (Curriculum framework for primary compulsory schools - elementary teaching in the Federal People's Republic of Yugoslavia, 1948) was considered very important for the future upbringing of students in the spirit of the communal ideology. Joint, choral singing meant that all students should be given the possibility to enjoy an undisturbed music development.

In the curriculum for elementary schools from 1952, Singing was present from the first to the fourth grade with one class per week. Teaching assignments (Educational Gazette, 1952) for all four grades were presented in the following manner: developing students' hearing, voice and correct pronunciation; developing the sense of rhythm and melody; inciting love of folk and art music in students; providing students with the basic knowledge of music history.

Only a year later, in the curriculum for lower grades of grammar schools and upper grades of eight-year schools (Educational Gazette, 1953), changes were implemented with regard to the number of planned teaching classes, and music teaching was conducted in the subject Singing only in the first and sec- ond grades of the grammar school (i.e. fifth and sixth grades of the eight-year school) with one class per week in the fifth grade, and two classes per week in the sixth grade.

In the manual for compressing the teaching curriculum for eight-year schools (Educational Gazette, 1957) regarding the course Singing, by means of a quantitative reduction of the teaching material and the development of new teaching areas, minor changes were implemented in the schedule of the curriculum and the transfer of the material from one grade to another. In the first and second grades, it was insisted on the children's activity by the use of different teaching aids, while rhythmic exercises and movements were most often performed through dance accompanied by music. In the third and fourth grades, all functions of the $\mathrm{C}$ major scale were learned without using the score, which was supposed to be taught in the fifth grade without much verbalism during the teaching process (Đurđanović, 2014).

From the above-mentioned, it is obvious that the curricula in the first post-war period both in Croatia and in Serbia frequently changed: from 1945 in Serbia and from 1946 in Croatia, music teaching included a onehour lesson per week. It was conducted with the same goal: the development of hearing and singing skills, with a focus on individual and choral singing, and encouraging the development of aesthetic and social skills in students.

Due to the meager capacities of the teaching staff, the first curricula centered on the contents that could be conducted without specific professional competences on the part of the teacher, so most of the teaching process came down to singing by ear.

Very soon, education policy introduced requests for sight singing, so theoretical literacy began to be insisted upon. According to the analyzed curricula, in Serbia, the acquisition of music literacy was introduced in 1947, and in Croatia, a year later. In the fifties, given that some areas had already had seven-year and eight - year schooling, the curriculum in the upper grades was moderately supplemented by the adoption of musical concepts.

In both Yugoslavian republics of the time, in accordance with the policy of the ruling party, the curricula completely excluded the content related to spiritual music. They were replaced by a large number of patriotic songs, and songs related to war, revolution, pioneers, etc. The emphasis on singing in the choir, in the spirit of the communal ideology, was evident first in the Croatian curriculum from 1948, while the same tendency could be 
found in the Serbian curriculum one year later. The number of teaching hours also varied in the fifties: e.g. according to the curriculum from 1950 in Croatia, music was taught for 2 hours per week in the fifth grade, while in Serbia, the curriculum from 1953 includes two hours of music teaching in the sixth grade. Only a few years later, in 1954, in Croatia, the number of music teaching hours was again brought back to one hour per week in all grades. It is interesting that in Croatia the subject Singing changed the name to Music education in 1951, while the same change took place 8 years later in Serbia. We come to the conclusion that the curricula in the early period after the war were similar but not identical, while the subject itself was taught under a different name.

While studying the teaching practice of the time, one should bear in mind that despite the detailed insight into the analyzed curricula, the situation in practice was certainly somewhat different; therefore, their implementation should be taken with caution. Due to unequal conditions in the field and the aforementioned difficult situation in the society at large (the poor social status of the population, demolished schools, the lack of teaching staff, textbooks and teaching aids), the first curricula were simply a kind of draft, which was the main source teachers used in accordance with the conditions of the area in which they worked.

Considering the fact that until the end of the fifties it was not customary to mention the names of the persons who took part in the creation of the curricula, their names are mostly unknown. They were designed in a closed circle of a number of people; and they were treated as a collective work by the Ministry of Education.

\section{FROM THE SCHOOL REFORM UNTIL THE FALL OF THE SECOND YUGOSLAVIA (1958-1990)}

In 1958, the General Law on Schools was adopted establishing a new system of schooling, education and upbringing, and legalizing compulsory eight-year education, while making the pre-school education an integral part of the education system (Krulj, 2011). During the reform process, which lasted a number of years, the importance of professional, innovative and pedagogically trained teaching staff came to light. The ruling party made attempts to replace authoritarian meth- ods of governance, prevalent in the first postwar years, with more democratic means. In the sixties, with the founding of pedagogical academies and faculties, at which the teaching staff could be educated, a thorough reform of the high education for teachers began. The transfer of the reform concept for primary compulsory schools was long and gradual. Educational pedagogical bodies and ideological commissions of the republics, within the Central Committee of the League of Communists of Yugoslavia, followed the process of harmonizing the school systems of the curricula in Yugoslavia and collecting data on the first experiences and difficulties. Educational goals were aimed at transferring communist knowledge, values and skills to students, and the concept of such an educational system was in complete material and program dependence on the party state (Rajčević, 2016, p. 169).

In Croatia, reform ideas are outlined in the comprehensive book 'The Primary compulsory school - Program Structure' (1958) which is not just a curriculum, but a unique interpretation of the fundamental ideas of the new school. The new school concept included the introduction of group work, free activities, new educational activities that enable students to progress individually, providing assistance to those who fall behind, and working with those who show interest in certain fields of study. The importance of satisfying special interests of individual students in various fields of creativity, culture, art, engineering and sports is emphasized through free activities. The aim was to develop cultural needs by organizing events in schools and taking students to programs outside their school, thus underlining the social role of the primary compulsory school as a cultural center and focal point. There was a more liberal atmosphere in schools, and pedagogical science began to gradually be open to new tendencies.

In 1958, a thought-out concept draft of musical education in primary compulsory schools at the federal level resulted in adopting a new curriculum in 1960. In the curriculum, along with singing, creativity, listening to music, literacy and learning various concepts of musical culture, playing was also introduced, so teachers had to pay attention to the complex task of teaching students how to perform a song on school instruments (Educational structure. Primary compulsory school, 1960). Music education had the highest number of teaching hours by that time: it took place in the first three grades four times half an hour per week, and from the fourth grade, two 
hours per week (that is, two hours per week in all grades). In the first three grades of the primary compulsory school music education was based on listening, singing, playing, and creative work. Playing referred to the instruments that students could master without any special difficulties. If the teacher had the necessary knowledge and school instrumentation, he/she was supposed to introduce instruction into playing traditional instruments as well.

From the fourth to the sixth grade, it was necessary to begin making the student's musical perception more explicit and conscious. Music education in these grades consisted of three segments: hearing development (listening, understanding and writing down bars, measures and rhythm, recognition, intonation and recording of scale/diatonic functions in the major and minor, knowing the means of interpretation/basic concepts of dynamics, tempo, articulation, etc., most important chromatic tones, modulation in parallel tonalities, two-part singing, cadences, oral, written, and analytic dictations and music memory exercises); taste development (singing and playing, listening to live and mechanic reproduction, learning and analyzing vocal and instrumental forms and their parts, concluding with a twopart and three-part song based on listening), and education for self-expression (beating, rhythm and tone recording, playing the percussion and simple melodic instruments, sight-singing, creative work, comprehension and appreciation of music, playing instruments). The focus of music education in the seventh and eighth grades was to acquire the basis of instrumental music by becoming familiar with instruments and listening (gramophone records, the radio, concerts, operas, etc.). Knowledge acquired in the previous grades was supplemented with listening observation, learning about musical instruments, types and forms of music, music professions, institutions, etc. (Educational structure. Primary compulsory school, 1960).

In the second, altered edition of the curriculum from 1964, and the third from 1965, teaching material and music activity were divided in three stages. In the first two (from the first to the third and from the fourth to the end of the sixth grade), the central element of music education was singing songs adapted to the developmental age of the child by their scope, text and aesthetic experience. In the final stage, emphasis was placed on singing the songs with a socially engaged content, including the republic and state anthems and other songs which had a ceremonial character. The field of creativity at all stages implied work on creative activities. Teachers were suggested to use movement, facial expression and art, voice and tonal improvisations on percussions, text improvisations, melodies, as well as the composition of smaller music pieces, etc (Educational structure. Primary compulsory school, 1965). The first stage of hearing development and education focused on developing predispositions in students who were to be prepared for acquiring sound, rhythmic, and melodic imagery, and for mastering music literacy with the help of counting rhymes, stories, imitation of rhythms from nature and work, recognition of noises, voices and tones from the environment, memory and reproduction of rhythmic and melo-rhythmic motifs and phrases, song recognition, etc. In the second stage, the acquisition of music literacy began, and the most indispensable theoretical knowledge about rhythm and measure was adopted (observing, performing and recording simple measures and familiarizing with complex combinations; observing, distinguishing, performing and recording rhythmic combinations; identifying, intoning and recording diatonic functions / bars of the scale and melodic elements in the major and minor; singing melodies with solmization, alphabet and a neutral syllable; mastering simple multi-part singing; conscious orientation based on key signatures and intoning in tonalities with three to four symbols in the key signature of the major and minor; familiarizing with the elements of music forms). In the third stage (the seventh and eighth grades), theoretical knowledge was expanded and supplemented with musicological contents (metro rhythmic structure, intonation and theory, managing singing and playing by notes, familiarizing with the themes and importance of areas of musical folklore).

Starting with this curriculum, the number of hours continued decreasing; music teaching was conducted three times for half an hour in the first four grades and two school hours in the second four grades.

Further decrease in the number of hours was brought by the next modification in the school curricula which took place in 1972 (Our primary compulsory school. Educational structure, 1974). Classes we conducted twice a week half an hour in the first and second grades, two hours from the third to the sixth grade, and one hour in the seventh and eighth grades. The subject changed the name and was now called Music Education; however the concept remained the same. The division into stages became even clearer; however, compared with the previous curriculum, the third 
stage didn't directly deal with literacy but with musicological content accompanied by listening to music. In that curriculum, songs accompanied by playing are proposed, and a new development was also the selection of instruments intended for playing; apart from rhythmic instruments, the use of tambourines, melodicas, harmonicas, guitars and mandolins was recommended.

Neither the next, i.e. last change of the curriculum (before the breakup of the former state) from 1984 (The curriculum of child rearing and elementary education. Linguistic-artistic field, 1984) brought about any conceptual novelty with regard to the previous programs. The curriculum had retained all the previous teaching areas, and more attention was paid to listening to music at all stages. The subject changed its name to Music culture, and it was included in the language-arts educational field. The number of hours remained the same; however, there was no longer the exact number of hours devoted to music education in the classroom, but the total hourly rate for the language-arts educational field was set, which in practice meant that every teacher in this field could decide whether to pay more or less attention to music contents. In the subject teaching, music culture was set for two hours in the fifth and sixth grades, and one hour in the seventh and eighth grades. In this curriculum, a modest attention was paid to popular music which from the middle of the fifties, thanks to radio and television programs, became more and more popular and it had a growing influence on young people.

In Serbia, primary compulsory education reforms which began in 1952 reached their full affirmation in 1959 (Educational Gazette, 1959). In terms of its organization and content, the new way of teaching was finally rounded up in 1984, but modifications made in that period also affected the change in the name of the subject. The name Singing was replaced in the 1960s by the name Music Education, and two decades later this name too was replaced by a new name - Music Culture (Đurđanović, 2017).

In 1959, the Council of Education of the People's Republic of Serbia adopted the Curriculum for the elementary school in the People's Republic of Serbia (Educational Gazette, 1959), which began to be applied the same year, from the first to the fourth grade in order to be gradually introduced in the rest of the grades every following year. This curriculum changed the name of the subject Singing to Music Education. The number of hours by grade was: two hours per week from the third to the sixth grade, while the number of hours for the rest of the grades remained unchanged (one hour per week). The content of the curriculum for the subject Music Education included the following elements: the first and second grades - rhythm through movement and counting rhymes, songs by ear in the range of the fifth or the sixth; the third grade - it was insisted on the distinction of all degrees of the major scale, without writing down the notes, while writing the notation, developing musical taste and free expression and singing of melodies in the range of $\mathrm{c} 1-\mathrm{c} 2$ were intended for the fourth and fifth grades; the sixth grade covered the major and minor keys (up to two symbols per key signature), irregular rhythmic patterns, intervals, homophony and polyphony, two-part and three-part forms; the seventh grade introduced the study of instruments, solely strings; while in the eighth grade, it was continued with the acquisition of the sound and appearance of the wind, stringed and keyboard instruments (Đurđanović, 2014).

Playing school instruments and listening to music with a goal to develop a sense of good music and a criticism towards negative occurrences in music (the most valuable achievements of musical art) was a part of the Curriculum for the primary compulsory school of 1963 (Educational Gazette, 1963). The above-mentioned curriculum included the acquisition of musical literacy, intonation and writing down the notes of the scale in the major and minor, singing one-part songs, practicing music memory (rhythmic and melodic) and educating musical taste. The novelty was paying special attention to fostering musical creativity for children.

Unlike the previous curricula, which were based on dull and verbal theorizing, the curriculum from 1974 (Educational Gazette, 1974), began to relate to the teaching practice. It was emphasized that, in the majority of cases, teachers did not have a plan on how to classify songs for particular grades, and that songs about our revolutionary past and the creation of the socialist motherland were not sufficiently present in classes; therefore, it was suggested that teachers of classroom and subject teaching pay special attention to songs of this type. The curriculum included teaching $\mathrm{Mu}-$ sic education two hours per week in the third and fourth grades only. It was recommended that classes be conducted half an hour twice a week in the first and second grades due to students' psycho-physical abilities. The goal was to develop at this age musical abilities not 
only by singing but also by playing children's games (games accompanied by singing). With respect to the previously-mentioned ones, in its content and tasks, the curriculum set higher demands for the subject itself and teachers, by which it expanded their pedagogical activity and demanded the expertise of teachers in their work. It was also recommended that all knowledge from elementary music literacy be processed on the structure and basis of folk songs and music.

Significant novelties in this curriculum were that every school had the obligation to form a school choir of lower and upper grades (the repertoire would include a variety of musical literature, mass, combat, and artistic songs of national and foreign authors, canons, original folk songs of peoples and national minorities of Yugoslavia), as well as the obligation to introduce optional (school orchestras and vocal ensembles) and free activities (Musical Youth, After-school Music Lessons for Music Lovers, After-school Lessons for Music Composers) for musically-gifted children.

The 1976 curriculum for some grades was designed to provide teachers with concrete instructions for the realization of Music Education teaching - to which teaching content one should pay particular attention: singing songs by ear and from the score (songs of the peoples and nationalities of the Socialist Federal Republic of Yugoslavia, songs from the Peoples Liberation War); children's music games; playing children's instruments; free music expression; listening to music; elementary music literacy; recognizing basic music forms and instruments. The content of the songs mostly referred to nature, society, brotherhood and unity of the peoples and nationalities of the Socialist Federal Republic of Yugoslavia, revolution, Tito and post-war construction and reconstruction. It was carefully indicated in the 1976 curriculum that listening to music in the upper grades (the seventh and eighth grades) should be used for getting acquainted with basic music forms (from the curriculum) without going into their detailed analysis (Educational Gazette, 1976), and that the primary goal of teaching (in all elementary school grades) was to provide students with general music knowledge so that they could understand the music life of their environment or continue their education in the music school with more opportunities for initiative and affirmation, as well as the application of various forms of their creative work. In this way, the principle of students' activity was incorporated as the cornerstone of Music Education.
In the joint curriculum of educational work in the primary compulsory school (Educational Gazette 1984/85), modifications included the change in the name of the subject (Music Education was replaced by the name Music Culture), and suggestions for didactical manuals and other additional literature which would provide teachers with instructions for conducting lessons were also given. The teaching tasks of Music Culture were largely equal to the previous ones, and they continued to emphasize singing, playing and listening to music as a way to foster students' love and understanding for traditional folk, artistic, but also popular music.

We can conclude that the requirements of every curriculum were more ambitious and more complex, especially at the end of the fifties, as it was thought that music education in the upper grades would be taught by professional staff. Improvement was also expected in the sixties, when the teachers who had graduated from Pedagogical academies began to work.

With respect to music fields, alongside singing, creative work, listening to music, acquiring literacy, getting acquainted with music terminology, playing instruments was introduced in Croatia in 1960 and in Serbia in 1963. Likewise, even though the novelty in the Serbian curriculum of the same year included nurturing music creativity, by analyzing the Croatian curriculum, it is obvious that creativity was fostered already in the 1951 curriculum. During the sixties, literacy and music theory continued to be widely present in both countries. In much the same way, in the mid-sixties in Croatia, three distinctive stages that depended on the grade were set: singing by ear - music literacy - processing of musical content.

The insistence on literacy was accorded with the demands of education policy on changing the social composition of the audience and professional musicians in the future. In the socialist society, the acquisition of music knowledge had to be available to everyone, and also to young people who for different reasons couldn't get music education at music schools. Therefore, the curricula were more like the solfeggio curricula than being aimed at the general acquisition of music culture. The general music culture, which focused on further individual music playing, as a preparation for the future participation of a young person in cultural and artistic life, was connected to the third stage. In it, together with the acquisition of music knowledge, particular 
songs were suggested to be sung and played on various instruments available to children.

The fulfillment of such ambitious tasks required a higher number of teaching hours, so in the first post-reform years, the number of hours in Croatia (Educational structure. Primary compulsory school, 1960) was the highest in the history of music education in general. The tendency to reduce the number of hours took place in the mid-sixties - the only curriculum from the seventies in Croatia, that of 1972, introduced an increase in the number of hours in the third and fourth grades to two hours; however, in the seventh and eighth grades, the number of hours was reduced to 1 hour, which was introduced in Serbia by the 1974 curriculum.

During the seventies, two curricula from 1974 and 1976 were in effect in Serbia. Students sang by ear and reading the notes, they played children's music games and instruments; they were encouraged to express themselves freely in terms of music, they listened to music, gained the basics of music literacy, and learned about basic music forms and instruments; hence, the same music activities were performed as in Croatia. In the same year, 1984, the name of the subject changed: in both Croatia and Serbia it became Music Culture however with different terms for ,,music" used in the Croatian (,glazba") and Serbian curriculum (,muzika”), coming from the terminological difference in the two language varieties. New requirements came into view, such as the introduction of popular, i.e. pop music in the classroom.

\section{CONCLUSION}

In this paper, plans and programs, documents and various scientific materials from Croatia and Serbia in the area of music are analyzed and compared. They are important for the historical developments in terms of basic music education, which, by changing its physiognomy and adapting to social and political conditions influenced the overall upbringing and education of students. With the aim of exploring what was happening in music teaching in the period from 1945 to 1990 and the legacy left behind after the independence of Croatia and Serbia, the idea was to systematize the material and find out which similarities and differences were in the setting up of curricula and how it reflected on educational practices.

By analyzing the curricula for music teaching in general primary compulsory ed- ucation in Croatia and Serbia from 1945 to 1990, one can observe modifications in the number of hours, the name of the subject, and the transition from active music playing and acquisition of elementary musical literacy to the concept of auditory observation and the acquisition of music terminology. The goal of music teaching was to develop listening by ear, promote singing skills, with a great respect for choral music, and to encourage the development of aesthetic and social skills of students.

Unlike the first post-war curricula, which ware defined by inarticulate usage of professional terminology, and whose goals and tasks changed every other year, at the end of the fifties, creators of educational policy detected critical areas, corrected the goals and tasks of music teaching and revised music teachers' role in accordance with newly acquired experiences and needs. Each subsequent curriculum was based on systematic professional analyses. The system of work was modified and upgraded, and explanations were carefully elaborated so that they could provide teachers with much more help in understanding the curriculum and conducting lessons.

After the independence of the two countries, music education in the primary compulsory school took on different characteristics by which it was modernized: the goals and tasks, the contents and the concept of the subject were re-evaluated. Thus, for example, an open model that sets listening to music as a dominant activity has been in force in Croatia since 2006, while other areas are variable: they are chosen by the teacher based on the students' interests and the equipment of a school, and, next to the aforementioned, the teacher has the opportunity to choose modes of work and materials necessary for the successful realization of the teaching unit (Vidulin, 2016).

In the past few years, in Serbia, several EU initiatives have been launched in order to improve the education system (Vidulin, Martinović Bogojević and Đurđanović, 2015). Act on the Foundations of the Educational System. Official Bulletin of the Republic of Serbia: Educational Bulletin, no 72, 2009, defines and develops Education standards next to establishing the system of quality, monitoring and evaluation. The way in which these standards are formulated and set up aims to strengthen the teaching staff in order for the teaching process to be realized, and to harmonize the requirements with a goal to develop competence in students. In order for the student to master the cognitive and aesthetic as- 
pect of musical experience, it is necessary for the curriculum to cover four interrelated fields without which it would not be possible to get a high-quality introduction to music. Accordingly, the four areas are: knowledge and understanding, listening to music, performing music and musical creativity articulated through the guidelines which define the requirements of the curriculum, taking into account the lowest, mid-level and highest aspects of students' achievements.

\section{Conflict of interests}

The authors declare no conflict of interest.

\section{REFERENCES}

Dobrivojević, I. (2014). Širenje osnovnog obrazovanja [The expansion of elementary education]. In Panić A (Ed.), Nikad im bolje nije bilo? Modernizacija svakodnevnog života u socijalističkoj Jugoslaviji (pp. 20-26). Beograd: Muzej istorije Jugoslavije.

Duraković, L. (2016). Music as the Educational Mean in the Making of the «Socialist Man»: Music Education in Primary Schools of Croatia (19451965). History of Education \& Children's Literature, 11(2). 267-291. http://web.a.ebscohost. com/abstract?direct $=$ true \&profile $=$ ehost\&scope $=$ site $\&$ authtype $=$ crawler $\&$ jrnl $=19711093 \& A N=$ $120131178 \& \mathrm{~h}=\mathrm{sPzZ} 4 \mathrm{RBrHSL} 282 \mathrm{dPGEDf4D1}$ XubjFPHCu3LdYEShqo\%2byAzXDGnEz3XU xbfoTcwePw\%2fZKI40WRf1ZSaDQuV\%2fb $9 \mathrm{bQ} \% 3 \mathrm{~d} \% 3 \mathrm{~d} \& \mathrm{crl}=\mathrm{c} \&$ resultNs $=\mathrm{AdminWebAu}$ th\&resultLocal=ErrCrlNotAuth\&crlhashurl=lo gin.aspx $\% 3$ fdirect $\% 3$ dtrue $\% 26$ profile $\% 3$ dehos t $\% 26$ scope $\% 3$ dsite $\% 26$ authtype $\% 3$ dcrawler $\% 2$ 6jrnl\%3d19711093\%26AN\%3d120131178

Duraković, L. (2017). „Odgajati za muziku, odgajati pomoću muzike". Glazbeni odgoj u osnovnim školama u ranome socijalizmu ["Educating for music, educating by means of music"]. In Duda I (Ed.), Stvaranje socijalističkog čovjeka. Hrvatsko društvo i ideologija jugoslavenskoga socijalizma (Pp. 40-59). Zagreb-Pula: Srednja Europa, Sveučilište Jurja Dobrile u Puli.

Đurđanović, M. M. (2014). Nastava muzike u Srbiji u 19. $i$ 20. veku [Music teaching in Serbia in the $19^{\text {th }}$ and $20^{\text {th }}$ centuries $]$. Niš: Univerzitet $u$ Nišu, Fakultet umetnosti u Nišu.

Đurđanović, M. M. (2017). Razvoj metodike muzičke nastave u Srbiji [The development of didactics of music in Serbia]. In Vidulin, S (Ed.), Glazbena pedagogiju u svjetlu sadašnjih $i$ budućih promjena 5 (pp. 514-525). Pula: Sveučilište Jurja Dobrile.

Glazbena kultura. Plan i programi odgoja i osnovnog obrazovanja. Jezično-umjetničko područje [The curriculum of child rearing and elementary education. Linguistic-artistic field] (No. 7) (1984). Zagreb: Vjesnik Republičkog komiteta za prosvjetu, kulturu, fizičku $i$ tehničku kulturu SR Hrvatske.

Jeremić, B. (2009). Istorijski osvrt na značaj pevanja na mlađem školskom uzrastu u nastavnim planovima i programima od 1948. do 1984. godine [Historical review of the importance of singing at the younger school age in curricula from 1948 to 1984]. Norma, 14(3), 307-322.

Koren, S. (2012). Politika povijesti u Jugoslaviji 1945-1960 [History policy in Yugoslavia 1945-1960]. Zagreb: Srednja Europa.

Krulj, R. (2011). Sistem obrazovanja u Jugoslaviji (1918-2000) [The education system of Yugoslavia (1918-2000)], Godišnjak Učiteljskog fakulteta u Vranju, 2, 99-117.

Munjiza, E., \& Lukaš, M. (2006). Pedagoško-psihološko osposobljavanje učitelja u visokoškolskim ustanovama. [The pedagogical-psychological training of teachers.]. Odgojne znanosti, $8(2$ (12), 361-383. https://hrcak.srce.hr/21071

Munjiza, E. (2009). Povijest hrvatskog školstva i pedagogije [The history of Croatian education and pedagogy]. Osijek: Sveučilište Josipa Jurja Strossmayera u Osijeku - Filozofski fakultet, Hrvatski pedagoško-književni zbor, ogranak Slavonski Brod.

Najbar-Agičić, M. \& Agičić, D. (2006). Nastava povijesti u Republici Hrvatskoj i njezina zloupor$a b a$ [History teaching in the Republic of Croatia and its misuse]. In Ramet SP \& Matić, D (Eds.), Demokratska tranzicija u Hrvatskoj: transformacije vrijednosti, obrazovanje, mediji (Pp. 169-191). Zagreb: Alineja.

Nastavni plan i program za osnovne škole u Narodnoj Republici Hrvatskoj [Curriculum for primary compulsory schools in the Republic of Croatia] (1946). Zagreb: Ministarstvo prosvjete Narodne Republike Hrvatske.

Nastavni plan i program za osnovne škole za školsku 1947/48. godinu [Curriculum for primary compulsory schools from 1947 and 1948 school years] (1947). Beograd: Prosveta.

Nastavni plan i program za osnovne škole [Curriculum for primary compulsory schools] (1948). Zagreb: Ministarstvo prosvjete NRH.

Nastavni plan i program za sedmogodišnje škole [Curriculum for seven-year schools] (1948). Zagreb: Ministarstvo prosvjete NRH.

Nastavni plan i program za osmogodišnje škole i niže razrede gimnazije, osnovne škole $i$ produžene tečajeve [Curriculum for eight-year schools and lower grades of the grammar school, primary compulsory schools and extended courses] (1950). Zagreb: Ministarstvo prosvjete NRH.

Nastavni plan $i$ program za osmogodišnje škole $i$ niže razrede gimnazija [Curriculum for eightyear schools and lower grades of the grammar school] (1951). Zagreb: Skolska knjiga, Ministarstvo prosvjete NRH, Odjel za školstvo.

Nastavni plan i program za narodne četverogodišnje škole i niže razrede osnovne škole [Curriculum for people's four-year schools and lower grades of primary compulsory schools] (1954). Zagreb: Savjet za prosvjetu, nauku i kulturu NRH.

Naša osnovna škola. Odgojno-obrazovna struktura [Our primary compulsory school. Educational structure] (1974). Zagreb: Zavod za unapređivanje osnovnog obrazovanja - Školska knjiga.

Novi nastavni plan i program za osnovne škole sa metodskim uputstvima za obradu pojedinih nastavnih predmeta [Curriculum for primary compulsory schools with didactical instructions for teaching particular subjects] (1945). Beograd: 
(IJCRSEE) International Journal of Cognitive Research in Science, Engineering and Education

Vol. 6, No. 1, 2018.

Ministarstvo prosvete.

Odgojno-obrazovna struktura. Osnovna škola [Educational structure. Primary compulsory school]. (1960). Zagreb: Savjet za prosvjetu NRH.

Odgojno-obrazovna struktura. Osnovna škola [Educational structure. Primary compulsory school. (1964). Zagreb: Savjet za prosvjetu NRH.

Odgojno-obrazovna struktura. Osnovna škola [Educational structure. Primary compulsory school] (1965). Zagreb: Savjet za prosvjetu NRH.

Okvirni nastavni plan za osnovne škole - Osnovna nastava u FNRJ [Curriculum framework for primary compulsory schools - elementary teaching in the Federal People's Republic of Yugoslavia] (1948). Beograd: Komitet za škole i nauku Vlade FNRJ.

Petrović-Todosijević, S. (2007). ,Šegrti u školi života” ili „Čekači u životnoj čekaonici”, detinjstvo u Federativnoj Narodnoj Republici Jugoslaviji [,Apprentices in the school of life" or "Waiting in the waiting room of life", childhood in the Federal People's Republic of Yugoslavia"]. In Katz, V (Ed.), Revizija prošlosti na prostorima bivše Jugoslavije (pp. 235-255). Sarajevo: Institut za istoriju u Sarajevu.

Požgaj, J. (1959). Metodika nastave muzičkog odgoja [Didactics of music education]. In Simleša, $\mathrm{P}$ (Ed.), Metodika elementarne nastave (pp. 220-224). Zagreb: Pedagoško književni zbor.

Pregrad, Z. (1973). Estetski odgoj [Aesthetic upbringing] In Šimleša, P (Ed.), Pedagogija (Pp.126-138). Zagreb: Pedagoško-književni zbor.

Prosvetni glasnik [Educational Gazette] (No. 9) (1952). Nastavni plan i program za osnovne škole. Beograd: Znanje

Prosvetni glasnik [Educational Gazette] (No. 8) (1953). Nastavni plan i program za niže razrede gimnazije i više razrede osmogodišnjih škola. Beograd: Znanje

Prosvetni glasnik [Educational Gazette] (No. 8) (1957). Uputstvo za sažimanje nastavnog programa za osmogdišnje škole. Beograd: Znanje

Prosvetni glasnik [Educational Gazette] (No. 8) (1959). Nastavni plan i program za osnovnu školu. Beograd: Znanje

Prosvetni glasnik [Educational Gazette] (No. 2) (1963). Nastavni plan i program za osnovnu školu. Beograd: Znanje

Prosvetni glasnik [Educational Gazette] (No. 2) (1974). Uputstvo o rasterećenju i osavremenjavanju nastave u osnovnoj školi. Beograd: Znanje

Prosvetni glasnik [Educational Gazette] (No. 6, 7, 8, 9) (1976). Pravilnik o zajedničkom planu i programu obrazovno-vaspitnog rada u osnovnoj školi. Beograd: Znanje

Prosvetni glasnik [Educational Gazette] (No. 3, 4, 5) (1984/85). Zajednički plan i program vaspitnoobrazovnog rada u osnovnoj školi. Beograd: Znanje

Puževski, V. (2003). Hrvatska osnovna škola od 1945. do 1990. godine [Croatian primary compulsory school from 1945 to 1990]. Anali za povijest odgoja, 2, 87-105.

Rajčević, P. (2016). Curriculum for primary schools and socio-economic system. Zbornik radova Učiteljskog fakulteta Prizren-Leposavić, (10), 163-174. doi:10.5937/zrufpl1610163R

Sarić, T. (2013). Đački domovi u Narodnoj Republici Hrvatskoj 1945. - 1954. - prosvjetne i odgo- jne ustanove ili ,azili za prehranu i noćenje”? [Students' dormitories in the People's Republic of Yugoslavia 1945-1954. - Educational and rearing institutions or ,asylums for food and sleeping"?]. Časopis za suvremenu povijest, 3, 441-459.

Vidulin, S. (2016). Reforms of the Education System in Croatia and Reflections on Music Teaching in Compulsory School. In Hadžić, F (Ed.), Music in Society (Pp. 345-358). Sarajevo: Musicological Society of the Federation of Bosnia and Herzegovina, Academy of Music, University of Sarajevo.

Vidulin, S., Martinović Bogojević, J. \& Đurđanović, M. M. (2015). Importance, structure and outcomes of the music program in the primary school: The experience of Croatia, Montenegro, and Serbia. International Journal of Cognitive Research in Science, Engineering and Education (IJCRSEE), 3(1), 67-79. http://ijcrsee.com/index.php/ijcrsee/article/view/67

Zakon o osnovama sistema obrazovanja $i$ vaspitanja, Službeni glasnik RS. Prosvetni glasnik, br. 72, (2009). [Act on the Foundations of the Educational System. Official Bulletin of the Republic of Serbia: Educational Bulletin, no 72, 2009]. 